\title{
Company Characteristics, Non-Audit Services Fee and Aggressive Tax Planning: A Conceptual Framework
}

\author{
Rosmaria Jaffar, Chek Derashid, Roshaiza Taha
}

To Link this Article: http://dx.doi.org/10.6007/IJARBSS/v11-i1/9036

DOI:10.6007/IJARBSS/v11-i1/9036

Received: 08 December 2020, Revised: 11 January 2021, Accepted: 15 January 2021

Published Online: 30 January 2021

In-Text Citation: (Jaffar et al., 2021)

To Cite this Article: Jaffar, R., Derashid, C., \& Taha, R. (2021). Company Characteristics, Non-Audit Services Fee and Aggressive Tax Planning: A Conceptual Framework. International Journal of Academic Research in Business and Social Sciences, 11(1), 994-1004.

\section{Copyright: @ 2021 The Author(s)}

Published by Human Resource Management Academic Research Society (www.hrmars.com)

This article is published under the Creative Commons Attribution (CC BY 4.0) license. Anyone may reproduce, distribute, translate and create derivative works of this article (for both commercial and non-commercial purposes), subject to full attribution to the original publication and authors. The full terms of this license may be seen at: http://creativecommons.org/licences/by/4.0/legalcode

\section{Vol. 11, No. 1, 2021, Pg. 994 - 1004}

Full Terms \& Conditions of access and use can be found at http://hrmars.com/index.php/pages/detail/publication-ethics 


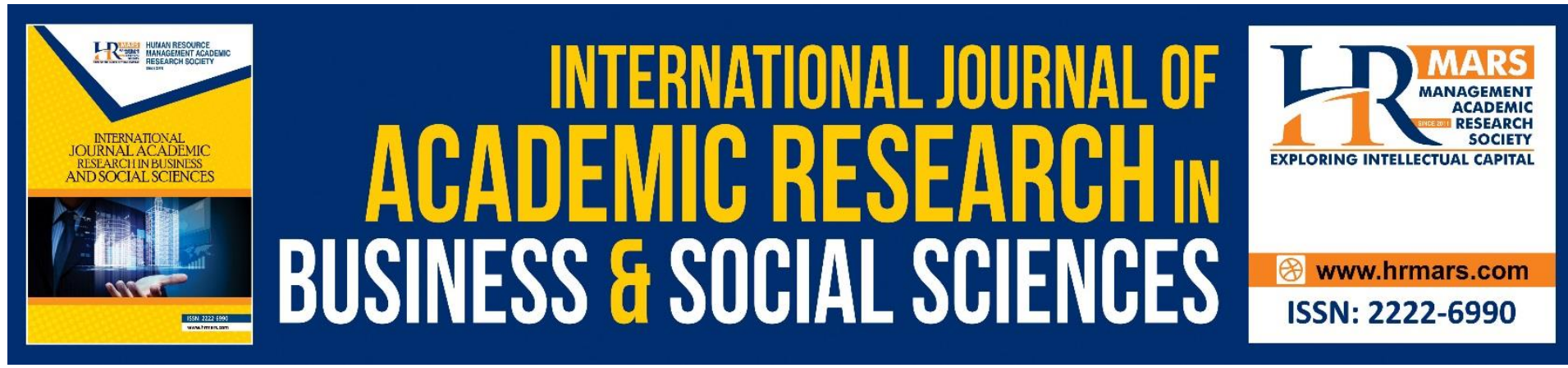

\title{
Company Characteristics, Non-Audit Services Fee and Aggressive Tax Planning: A Conceptual Framework
}

\author{
Rosmaria Jaffar \\ Faculty of Business and Management, Universiti Sultan Zainal Abidin \\ 21030, Kuala Nerus, Terengganu, Malaysia \\ Email: rosmaria@unisza.edu.my \\ Chek Derashid \\ Tunku Putri Intan Safinaz, School of Accounting Universiti Utara Malaysia \\ 60100, Sintok, Kedah, Malaysia \\ Email: chek@uum.edu.my
}

\section{Roshaiza Taha}

Faculty of Business, Economics and Social Development Universiti Malaysia Terengganu

21030, Kuala Nerus, Terengganu, Malaysia

Email: roshaiza@umt.edu.my

\begin{abstract}
This study aims to propose a research model on aggressive tax planning behaviour among listed companies in the Malaysian ACE market. There is no mutual decision on the relationship between company characteristics and tax planning in previous studies. Based on a thorough review of previous studies, the inconsistency was due to the utilization of other variables. Therefore, in this study, we introduced the moderating variable of non-audit services fee. Referring to the agency theory, non-audit services fee play a significant role in the relationship between company characteristics and aggressive tax planning behaviour since this fee is also one of the operating costs bear by companies. To have a deeper understanding on the role of non-audit services fee, this study will analyze further the role of this fee by introducing this fee as a moderator to see the interaction in the relationship between company characteristics and aggressive tax planning. It is hoped that the information provided in this study may help in understanding the role of non-audit services fee in reducing the companies tax burden. Besides, tax authorities may use the information in this paper as one of the criteria in choosing the sample for audit purposes.
\end{abstract}

Keywords: Aggressive Tax Planning, Malaysia, ACE Market, Size, Profitability, Leverage, Capital Intensity, Inventory Intensity, Non-Audit Services Fee. 


\section{Introduction}

Research on tax planning has been widely debated in recent years and become significant to tax policymakers, regulators, including tax authorities, corporate directors, investors, and academic researchers (Martinez, 2017). Studies such as Adhikari, Derashid, and Zhang (2006); Derashid and Zhang (2003); Filip and Lazăr (2011); Gupta and Newberry (1997); Hsieh (2012); Richardson and Lanis (2007); Wang, Campbell, and Johnson (2014); Wu, Wang, Luo, and Gillis (2012) had tested many variables in determining the factors that contributed to the differences between effective tax rate (ETR) and statutory tax rate (STR) in tax planning. In these studies, company characteristics such as size, return on assets, leverage, capital intensity, and inventory intensity created variation in ETR across companies. Thus, corporate characteristics were suggested to be an important variable in determining tax aggressiveness which is one of the tax planning categories exercised by companies (Devi, Salim, \& Pheng, 2018). However, there were inconclusive findings from the previous studies on the relationship between company size, profitability, leverage, capital intensity, inventory intensity, and tax planning between countries as well as in the country itself (Hadjidema, Stamatopoulos, \& Eleftheriou, 2016; Kim \& Im, 2017; Mascagni \& Mengistu, 2018; Nomura, 2017; Parisi, 2016; Pratama, 2017; Vintilă, Gherghina, \& Păunescu, 2018). For example, the relationship between size and ETR, Hadjidema et al., (2016) found a positive relationship while Kim and Im, (2017) found a negative relationship. In other studies, Minnick and Noga (2010) and Vintilă et al., (2018) found that there is no significant relationship between leverage and tax planning while others found there is a significant relationship. Thus, previous studies confirm that there are variations and inconsistencies in factors influencing tax planning activities.

Baron and Kenny (1986) indicated that the moderating variable is introduced when there are inconsistent relations between the study variables. Due to no uniformity in the relationship, this subject of research needs further investigation. Thus, in this study, the nonaudit services fee is introduced as a moderating variable. One might be said this may only add to another result, but the output will provide a new view in line with the development in this field. A new study may consider new variables that might be unique due to political, territorial, regulations and cultural differences. Considering this, our study aims to propose a new research model on aggressive tax planning behaviour among listed companies in the Malaysian ACE market, which is one of the alternative markets that help small and medium companies be listed in Bursa Malaysia. The discussion will focus on the role of non-audit services fee as based on a thorough investigation of the un-uniformity of the relationship between company characteristics and tax planning might due to other variables. As we mentioned previously, the relationships between company's characteristics and tax planning are inconsistent in previous studies. Such inconsistency creates a gap that needs to be filled. Additionally, the increasing number of companies tax audit resolve from 79,642 cases in 2011 to 178,583 cases in 2017 (Inland Revenue Board of Malaysia, 2017) make this study more significant to be investigated. Therefore, it is important to introduce the moderating variable in this study to examine the factors that contribute to aggressive tax planning activities. Thus, this paper aims to answer the following question: - Does non-audit services fee moderate the relationship between corporate characteristics (size, profitability, leverage, capital intensity, inventory intensity) and aggressive tax planning among companies listed on the ACE Market? 
The discussion of this paper was structured as follows; section 2 discusses the theory and past studies as well as hypothesis development, section 3 explains the research framework, section 4 describes the research methodology and the last section concludes the study.

\section{Literature Review \\ Agency Theory}

Agency theory can be defined as a contract between the principal who engages the agent to perform services on their behalf, which involves delegating some decision making authority to the agent (Jensen \& Meckling, 1976). Based on the agency theory perspectives, managers may choose whether to engage in more or less tax aggressiveness than in maximizing shareholders' value due to the absence of monitoring and their involvement in day-to-day operations (Desai \& Dharmapala, 2006; Rego \& Wilson, 2012). Therefore, to solve the information asymmetry between manager and shareholder and also to reduce the agency cost, it is an important responsibility for companies to hire external auditors with a good reputation (Alshawish, Abed, \& Hamadallah, 2015). In this situation, the auditor will act as an agent for the shareholders whose interests are considered different to those of the managers of the companies audited (Jensen \& Meckling, 1976). Auditor which provides non-audit services such as tax service can help a company in providing effective tax planning.

\section{Non-Audit Services Fee}

Prior to 2001, the disclosure of non-audit services fee is not compulsory in Malaysia. However, with the amendment of Bursa Malaysia Listing Requirement Regarding Transparency on 1 June 2001, all listed companies must disclose the amount of non-audit services fee paid to external auditors in their annual reports but this new requirement, with respect to the non-audit fees, does not specify the manner of the disclosure (Refer to Chapter 9 under Paragraph 9.25 of Appendix 9c in Part A number 17 of the Bursa Malaysia Listing Requirement). However, in 2016, the details of the NAS fee must be disclosed if it is significant. Non-audit services were defined as any services provided by an auditor other than audit services which included management advisory services or consulting and also included tax services and accounting advice (Haron, Ismail, Ganesan, \& Hamzah, 2016). In addition, Firth (1997) defined non-audit services which include tax consultancy, systems consultancy, management advice, international business advice, human resource management, and financial and investment consultancies.

Other researchers defined non-audit services as fees paid by the companies to the auditor who provided non-audit services (Santos, Cerqueira, \& Brandao, 2015); and also any services provided by an auditor other than audit services which included management advisory services, consulting which also included tax services and accounting advice (Haron et al., 2016). However, Choudhary and Koester (2017) defined non-audit service fees as fees paid to audit firms for tax services. Due to the Enron scandals, the Sarbanes-Oxley Act (SOX) has been implemented to help protect investors from fraudulent financial reporting by companies. The passage of SOX imposed strict limitations on the types of non-audit services that audit firms could provide to their audit clients. Thus, the fees paid for non-audit services required to be disclosed separately by companies based on their type, especially for tax services (Hogan \& Noga, 2015). 
Therefore, tax services play as an important service obtained by companies. It is in line with the study by Ong et al. (2008) cited in Ganesan, Haron, Ismail, and Pitchay (2017) where they found that business such as small and medium enterprise (SME) find additional services from the external accountant regarding six matters as follows; (i) accounting services, (ii) taxation services, (iii) assurance services, (iv) corporate services, (v) corporate finance services and ( $\mathrm{vi}$ ) business consulting services. From all of the services provided, the most priority services sought after by SME is taxation services. This finding was supported by Choudhary and Koester (2017) that companies usually hired tax advisors which is an external tax professional for giving services for them in terms of income tax compliance and planning services. Study also found that the relationship between auditor and SME not just because of the audit services given by the auditor, but the auditor also acted as an advisor in order to support business activities of SME [Companies Commission of Malaysia (CCM), 2017].

Previous study also suggests that companies must recruit qualified employees to be involved in tax planning activities (Laguir, Elbaz, \& Laguir, 2015; Mgammal, 2015). This is because companies which are not expert in planning their tax will get a minimum benefit from the strategy use due to the limited knowledge that they have. It was affirmed by Tee, Boadi and Opaku (2016) where they found that 56\% of SME in GA West Municipal which not hired tax advisors have limited knowledge about the core tax system and its legalities. From this study, it can be concluded that small and medium companies have limited knowledge about tax matters which is very important to help them minimize their tax burden. Therefore, tax arrangement is an important activity for businesses where most of the companies hired professionals to provide this expertise (The Star, 2017).

Due to that, the non-audit services fee is seen as significant in tax planning. Utilizing actual data from Internal Revenue Services (IRS) for 1,533 firm-years during 2008 and 2009, Klassen et al. (2016) found that auditor-provided tax service has a relationship with tax aggressiveness. Consequently, tax aggressiveness companies were found to pay higher fees for external audit services (Donohoe and Knechel, 2014). The output of this study was then supported by Chyz et al. (2017). They found that companies that paid their auditor for tax services received a reduction in ETR, higher cash tax savings and lower risk than companies that did not involve their auditor for tax services. Also, studies were done by Burggrael et al. (2017); and Saremi, Mohammadi, and Nezhad (2016) found a similar result where non-audit services fee has influenced the level of tax planning in the companies. Although their studies conducted in a different country which is in German and Tehran respectively, but the negative relationship highlighted that the higher the non-audit services fee, the lower the companies' ETR. The finding of this study supports the result found by McGuire, Omer, and Wang (2012) where they found that companies receive simultaneously audit services and tax services from their auditor encourage them to conduct aggressive tax planning behaviour.

Similarly, study in Malaysia also found that auditors provided tax services have a significant relationship with tax planning activities (Hussin \& Noor, 2012) indicating that SME with higher auditor provided tax services fee have lower ETR. In this study, the variable of auditor-provided tax services has been measured by using audit fees divided by total assets. Tax services are one of the types of non-audit services. As mention by previous researchers, non-audit services fee includes tax services and become the most services requested by small 
and medium companies (Firth, 1997; Ganesan et al., 2017; Haron et al., 2016; Volckaert, 2016).

Previous studies indicated the inconsistent result between company characteristics and ETR. For example, the relationship between company size and ETR, some of these studies found a positive and significant relationship (Mascagni \& Mengistu, 2018; Nomura, 2017; Parisi, 2016; Pratama, 2017; Vintilă et al., 2018; Yinka \& Uchenna, 2018). Other studies found a negative and significant relationship (Kim \& Im, 2017; Savitri, 2017; Wahab et al., 2017). Furthermore, there was an inconsistent result in the previous studies between profitability and ETR. For example, Parisi (2016); Pratama (2017); Savitri (2017) found a negative and significant relationship between profitability and ETR while others found a positive and significant relationship between profitability and ETR (Hadjidema et al., 2016; Kim \& Im, 2017; Yinka \& Uchenna, 2018).

The relationship between capital intensity and ETR also has a contradict result. Kim and Im (2017); Parisi (2016); and Vintilă et al. (2018) found a positive relationship while Savitri (2017) and Wahab et al. (2017) found a negative relationship. In terms of the relationship between inventory intensity and ETR, Vintilă et al. (2018) and Yinka and Uchenna (2018) found a positive and significant relationship while Hadjidema et al. (2016) and Savitri (2017) found a negative relationship. Also, there is a conflict result between leverage and ETR. The negative relationship was found by previous studies (for example Mascagni \& Mengistu, 2018; Nomura, 2017; Yinka \& Uchenna, 2018) while, a positive relationship between leverage and ETR was found by Savitri (2017); Wahab et al., (2017). Conversely, the relationship between leverage and ETR was found insignificant by Minnick and Noga (2010) and Vintilă et al. (2018). Therefore, due to this inconsistency, this study proposed the use of non-audit services fee as a moderating variable to investigate the relationship between company characteristics and aggressive tax planning.

Therefore, from the above discussion, we believe that the rigorous tax planning activities conducted by companies are moderate by non-audit services fee. Therefore, we proposed the following hypotheses:

$\mathrm{H} 1$ : The relationship between company size and aggressive tax planning among companies listed in the ACE market at Bursa Malaysia is moderated by non-audit services fee.

$\mathrm{H} 2$ : The relationship between profitability and aggressive tax planning among companies listed in the ACE market at Bursa Malaysia is moderated by non-audit services fee.

H3: The relationship between capital intensity and aggressive tax planning among companies listed in the ACE market at Bursa Malaysia is moderated by non-audit services fee.

$\mathrm{H} 4$ : The relationship between inventory intensity and aggressive tax planning among companies listed in the ACE market at Bursa Malaysia is moderated by non-audit services fee.

$\mathrm{H} 5$ : The relationship between leverage and aggressive tax planning among companies listed in the ACE market at Bursa Malaysia is moderated by non-audit services fee.

\section{Research Framework}

Based on the agency theory, this study proposed that by introduce non-audit services fee in the relationship between company characteristics and aggressive tax planning might 
reduce the inconsistency in previous literature. The proposed research framework is depicted in Figure 1. In this framework, this study proposed five independent variables, namely company size (SIZE), profitability (ROA), capital intensity (CAPIN), inventory intensity (INVENT) and leverage (LEV). The non-audit services fee (NASF) is a moderating variable, while the dependent variable is aggressive tax planning (ATP).

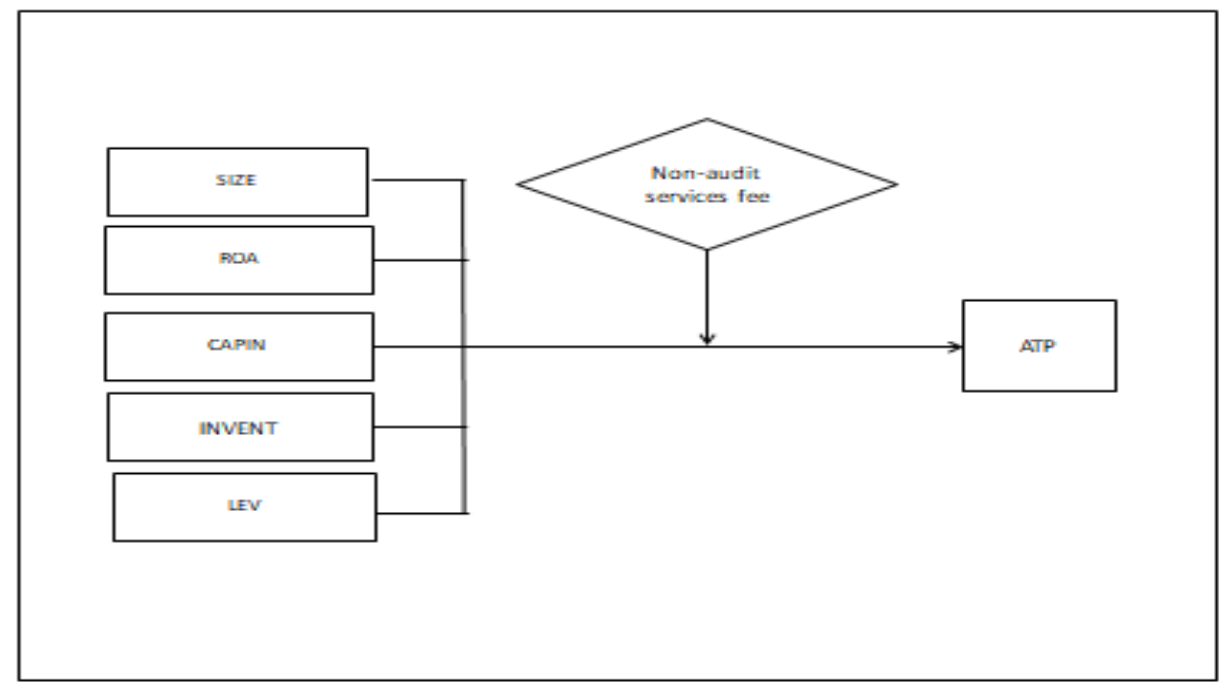

Figure 1: Proposed Research Framework

\section{Research Methodology}

The data will be collected from DataStream software and the downloaded annual reports. This study will focus on Malaysian companies listed in the ACE Market of Bursa Malaysia from 2014 to 2018 which exclude the following criteria: 1) companies listed after 2014; 2) finance/insurance/bank/trust companies; 3) companies with missing data; 4) lossmaking companies a least in one of the years with negative profit. After the data have been collected, the screening process will be conducted to ensure there is no outlier in the data. Then, the data will be analyzed using STATA Software. At the end of this study, it is expected that the effect of non-audit services fee as an interaction term between the companies' characteristics and aggressive tax planning will be revealed. The equation for this proposed framework is as follows:

$$
\begin{aligned}
& A T P_{i t}=60+61 S I Z E_{i t}+62 R O A_{i t}+63 C A P I N_{i t}+64 I N V E N T_{i t}+65 L E V_{i t}+68 N A S F_{i t}+69 S I Z E_{i t} \\
& { }^{*} N A S F_{i t}+\text { B10ROA it }{ }^{*} N A S F_{i t}+\text { B11CAPIN it }{ }^{*} N A S F_{i t}+\text { B12INVENT it }{ }^{*} N A S F_{i t}+ \\
& \text { B13LEV it }{ }^{*} N A S F_{i t}+\varepsilon_{i t}
\end{aligned}
$$

\section{Conclusion}

The purpose of this paper was to propose a conceptual framework for examining the influence of non-audit services fee on the relationship between companies' characteristic (size, profitability, capital intensity, inventory intensity, leverage) and aggressive tax planning amongst companies listed in the Malaysian ACE Market. Therefore, to determine whether non-audit services fee influence the relationship, the proposed framework of this study has introduced a non-audit services fee as a moderating variable. Although previous studies have examined the relationship between auditor provided tax services fee and aggressive tax 
planning, but there is a limited study that investigates the use of non-audit services fee as a moderating variable.

Thus, the framework presented in this paper may be useful for future financial accounting and taxation research aiming to reveal the importance of non-audit services fee in influencing aggressive tax planning behaviour. Besides, the result of this study can provide new knowledge on tackling aggressive tax planning behaviour among companies where the result can be suggested to use as one of the criteria in choosing an audit sample by the tax authority. This study is also expected to provide more evidence from an emerging market on the relationship between companies' characteristics, non-audit services fee, and aggressive tax planning.

\section{Acknowledgement}

We thank the editor and the anonymous reviewers for their helpful comments and suggestion for this paper.

\section{Corresponding Author}

Chek Derashid

Tunku Putri Intan Safinaz, School of Accounting, Universiti Utara Malaysia 60100, Sintok, Kedah, Malaysia

Email:chek@uum.edu.my

\section{References}

Adhikari, A., Derashid, C., \& Zhang, H. (2006). Public policy, political connections, and effective tax rates: Longitudinal evidence from Malaysia. Journal of Accounting and Public Policy, 25(5), 574-595. https://doi.org/10.1016/j.jaccpubpol.2006.07.001

Alshawish, M., Abed, S., \& Hamadallah, M. (2015). The Impact of Agency Cost on Demand for Non-Audit Services for Listed Corporations in Jordan. International Journal of Economics and Finance, 7(7), 154-162. https://doi.org/10.5539/ijef.v7n7p154

Baron, R. M., \& Kenny, D. A. (1986). The Moderator-Mediator Variable Distinction in Social Psychological Research : Conceptual , Strategic, and Statistical Considerations. Journal of Personality and Social Psychology, 51(6), 1173-1182.

Burggrael, S., Wtrin, C., \& Wei, F. (2017). Discovering the Concealed Benefits of AuditorProvided Tax Services.

Choudhary, P., \& Koester, A. (2017). Auditor-Provided Tax Services and Income Tax Estimation Error.

Chyz, J. A., Naiker, V., Gal-Or, R., \& Sharma, D. (2017). The influence of auditor provided tax planning and tax compliance services in the "tax transparency era ." In Tax-Symposium2017 (pp. 1-54).

Companies Comission of Malaysia (CCM). (2017). Audit exemption for selecte categories of private companies| Suruhanjaya Syarikat Malaysia (SSM). Retrieved from http://www.ssm.com.my/en/press-release/audit-exemption-selected-categoriesprivate-companies

Derashid, C., \& Zhang, H. (2003). Effective tax rates and the "industrial policy" hypothesis: Evidence from Malaysia. Journal of International Accounting, Auditing and Taxation, 12(1), 45-62. https://doi.org/10.1016/S1061-9518(03)00003-X 
Desai, M. A., \& Dharmapala, D. (2006). Corporate tax avoidance and high-powered incentives. Journal of Financial Economics, 79(1), 145-179. https://doi.org/10.1016/j.jfineco.2005.02.002

Devi, M. N., Salim, A. S. A., \& Pheng, L. K. (2018). The Impact of Firm Characteristics on Corporate Tax Aggressiveness: A Study on Malaysian Public Listed Companies. Advanced Science Letters, 24(4), 2208-2212. https://doi.org/https://doi.org/10.1166/asl.2018.10918

Donohoe, M. P., \& Knechel, R. W. (2014). Does corporate tax aggressiveness influence audit pricing? Contemporary Accounting Research, 31(1), 284-308. https://doi.org/10.1111/1911-3846.12027

Filip, G., \& Lazăr, S. (2011). Measuring Corporate Effective Tax Burden in Romania: a Comprehensive Approach. Scientific Annals of the Alexandru Ioan Cuza University of lasi : Economic Sciences Series, 2011(LVIII), 133.

Firth, M. (1997). The Provision of Non-audit Services. Journal of Business Finance \& Accounting, 24(April), 511-525.

Ganesan, Y., Haron, H., Ismail, I., \& Pitchay, A. A. (2017). Do Small and Medium Practitioners' ( SMPs') Service Quality and Non-Audit Service Fees Paid Matters'? The Mediating Role of Satisfaction of Small Medium Enterprises (SMEs). Global Business and Management Research: An International Journal, 9(4), 391-409.

Gupta, S., \& Newberry, K. (1997). Determinants of the Variability in Corporate Effective Tax Rates: Evidence from Longitudinal Data. Journal of Accounting and Public Policy, 16(1), 1-34. https://doi.org/10.2753/REE1540-496X5004S4007

Hadjidema, S., Stamatopoulos, I., \& Eleftheriou, K. (2016). Explaining Corporate Effective Tax Rates Before and During the Financial Crisis: Evidence from Greece. Munich Personal RePEc Archive. Retrieved from https://mpra.ub.uni-muenchen.de/73787/

Haron, H., Ismail, I., Ganesan, Y., \& Hamzah, Z. (2016). Audit Exemption for Small and Medium Enterprise: Perceptions of Malaysian Auditors. Asian Academy of Management Journal, 21(2), 153-182. https://doi.org/10.21315/aamj2016.21.2.7

Hogan, B., \& Noga, T. (2015). Auditor-provided tax services and long-term tax avoidance. Review of Accounting and Finance, 14(3), 285-305. https://doi.org/http://dx.doi.org/10.1108/RAF-10-2013-0116

Hsieh, Y. (2012). New evidence on determinants of corporate effective tax rates. African Journal of Business Management, 6(3), 1177-1180. https://doi.org/10.5897/AJBM11.1522

Hussin, S. N., \& Noor, R. M. (2012). The dual role of auditor-provided tax services (ATS) in SMEs tax planning. In CHUSER 2012 - 2012 IEEE Colloquium on Humanities, Science and Engineering Research (pp. 351-356). https://doi.org/10.1109/CHUSER.2012.6504338

Inland Revenue Board of Malaysia. (2017). Annual Report IRBM. Inland Revenue Board of Malaysia.

Jensen, M. C., \& Meckling, W. H. (1976). Theory of Firm:Managerial Behaviour, Agency cost, and Ownership Structure. Journal of Financial Economics, 3, 305-360.

Kim, J. H., \& Im, C. C. (2017). The study on the effect and determinants of small-and mediumsized entities conducting tax avoidance. Journal of Applied Business Research, 33(2), 375-390. 
Klassen, J. K., Lisowsky, P., \& Mescall, D. (2016). The role of auditors, Non-Auditors, and internal tax departments in corporate tax aggressiveness. In Accounting Review (Vol. 91, pp. 179-205). https://doi.org/10.2308/accr-51137

Laguir, I., Elbaz, J., \& Laguir, L. (2015). Empirical evidence on SMEs' tax management. Applied $\begin{array}{lll}\text { Economics Letters, 22(14), 1133-1137. } & \text { 22 }\end{array}$ https://doi.org/10.1080/13504851.2015.1008757

Martinez, A. L. (2017). Tax aggressiveness: a literature survey. Journal of Education and Research in Accounting, 11 (special edition), 104-121. https://doi.org/http://dx.doi.org/10.17524/repec.v11i0.1724

Mascagni, G., \& Mengistu, A. (2018). Effective tax rates and firm size in Ethiopia. Development Policy Review, 1-40. https://doi.org/10.1111/dpr.12400

McGuire, S. T., Omer, T. C., \& Wang, D. (2012). Tax avoidance: Does tax-specific industry expertise make a difference? Accounting Review, 87(3), 975-1003. https://doi.org/10.2308/accr-10215

Mgammal, M. H. (2015). The Effect of Tax Planning and Corporate Governance on Tax Disclosure in Malaysia. Universiti Utara Malaysia.

Minnick, K., \& Noga, T. (2010). Do corporate governance characteristics influence tax management?. Journal of Corporate Finance, 16(5), 703-718. https://doi.org/10.1016/j.jcorpfin.2010.08.005

Nomura, H. (2017). What Determines Japanese Corporate Effective Tax Rates ? Evidence from Firms Listed on the Tokyo Stock Exchange, (June), 1-18. Retrieved from http://apeaweb.org/confer/seoul17/papers/Nomura_Hiroyasu.pdf

Parisi, V. (2016). The determinants of Italy's corporate tax rates: an empirical investigation. Public and Municipal Finance, 5(4), 7-14. https://doi.org/10.21511/pmf.05(4).2016.01

Pratama, A. (2017). Company Characteristics, Corporate Governance and Aggressive Tax Avoidance Practice : A Study of Indonesian Companies. Review of Integrative Business and Economics Research, 6(4), 70-81.

Rego, S. O., \& Wilson, R. (2012). Equity Risk Incentives and Corporate Tax Aggressiveness. Journal of Accounting Research, 50(3), 775-810. https://doi.org/10.1111/j.1475679X.2012.00438.x

Richardson, G., \& Lanis, R. (2007). Determinants of the variability in corporate effective tax rates and tax reform: Evidence from Australia, 26, 689-704. https://doi.org/10.1016/j.jaccpubpol.2007.10.003

Santos, C., Cerqueira, A., \& Brandao, E. (2015). Audit Fees, Non-Audit Fees and Corporate Performance, (December), 1-27.

Saremi, H., Mohammadi, S., \& Nezhad, B. M. (2016). Relationships between Effective Tax Rate and Audit Fees: Evidence from Tehran Stock Exchange. International Journal of Management and Humanities, 2(7), 120-127.

Savitri, E. (2017). Determinants of Effective Tax Rate of the Top 45 largest listed companies of Indonesia. International Journal of Management Excellence, 9(3), 1183-1188.

Tee, E., Boadi, L. A., \& Opoku, R. T. (2016). The Effect of Tax Payment on the Performance of SMEs : The Case of Selected SMEs in Ga West Municipal Assembly. ResearchGate, 8(20), 119-125.

The Star. (2017). Tackling aggressive tax planning. The Star Online. Retrieved from https://www.thestar.com.my/opinion/columnists/the-star-says/2017/01/18/tacklingaggressive-tax-planning 
Vintilă, G., Gherghina, Ş. C., \& Păunescu, R. A. (2018). Study of Effective Corporate Tax Rate and Its Influential Factors: Empirical Evidence from Emerging European Markets. Emerging Markets Finance and Trade, 54(3), 571-590. https://doi.org/10.1080/1540496X.2017.1418317

Volckaert, K. (2016). The Role of the Financial Sector in Tax Planning Harmful tax practices and fiscal competition, 46.

Retrievedfromhttp://www.europarl.europa.eu/RegData/etudes/STUD/2016/578980/I POL_STU(2016)578980_EN.pdf

Wahab, E. A. A., Ariff, A. M., Marzuki, M. M., \& Sanusi, Z. M. (2017). Political connections, corporate governance, and tax aggressiveness in Malaysia. Asian Review of Accounting, 25(3), 424-451. https://doi.org/10.1108/ARA-05-2016-0053

Wang, Y., Campbell, M., \& Johnson, D. (2014). Determinants of effective tax rate of China publicly listed companies. International Management Review, 10(1), 10-20. Retrieved from http://www.scholarspress.us/journals/IMR/pdf/IMR-1-2014/v10n1-art-2.pdf

Wu, L., Wang, Y., Luo, W., \& Gillis, P. (2012). State ownership, tax status and size State ownership, tax status and size effect of effective tax rate in China, (June 2013), 37-41.

Yinka, M. S., \& Uchenna, C. E. (2018). Firm specific determinants of corporate effective tax rate of listed firms in Nigeria. Journal of Accounting and Taxation, 10(2), 19-28. https://doi.org/10.5897/JAT2017.0288 